\title{
Water Rights and Social Justice in the Mekong Region
}

Authors: Patricia Wouters, and Kenneth Kang

Source: Mountain Research and Development, 33(1) : 116-117

Published By: International Mountain Society

URL: https://doi.org/10.1659/mrd.mm117

BioOne Complete (complete.BioOne.org) is a full-text database of 200 subscribed and open-access titles in the biological, ecological, and environmental sciences published by nonprofit societies, associations, museums, institutions, and presses.

Your use of this PDF, the BioOne Complete website, and all posted and associated content indicates your acceptance of BioOne's Terms of Use, available at www.bioone.org/terms-of-use.

Usage of BioOne Complete content is strictly limited to personal, educational, and non-commercial use. Commercial inquiries or rights and permissions requests should be directed to the individual publisher as copyright holder. 


\section{Water Rights and Social Justice in the Mekong Region}

Edited by Kate Lazarus, Nathan Badenoch, Dao Nga, and Bernadette P. Resurreccion. London, United Kingdom: Earthscan, 2011. $x i x+265$ pp. $£ 60.00$, US\$105.00. ISBN 978-1-84971-1883-3.

Water rights and social justice in the Mekong region are vast topics. This book uses a theoretical concept of social justice, "what is good for society” (p 4), to explore a range of issues linked to the governance of water resources across the Mekong. Despite its title, the work contains little reference to legal frameworks (ie treaties and national laws) but instead adopts a social science approach to explore various aspects of water rights and social justice, and to examine how the diverse communities that share the Mekong are affected.

The book comprises 11 chapters, organized into 5 parts (including the conclusion), with the following main headings: Part I-Participation in Decision-Making (2 chapters), Part II-Social Differences and Access (3 chapters), Part III-Competing Demands and Protecting the Rights of the Marginalized (2 chapters), and Part IV-Climate Change and the Rights of the Vulnerable (2 chapters). The work's distinguishing feature is its collection of local stories that provides the context for analyzing local practice through the central theme of the work: how, and to what extent, Habermas' ideal society-free from domination, more democratic, and with a stronger civil societymight still be conceivable across the Mekong region.

Legal scholars might find the book's title misleading, because there is a marked absence of law in the entire work; the index cites only 5 pages that include "law," and there is no entry for "treaty," which, for lawyers concerned with the legal regimes that govern the Mekong, would be inadequate. We would have liked more references to legal regimes (international, regional, and national) that appreciate how these affect water rights and social justice across the Mekong, but perhaps this was beyond the scope of the study, as stated clearly in the collectively written opening chapter. In this light, however, lawyers would discover an innovative and fresh approach to water rights and social justice with unique case studies on offer.

So what new insights does this approach bring to the table? Compared with other recent publications, for example, Glassman (2010), the book excels in its rich array of multidisciplinary contributors drawn not only from the developed West, but also directly from the region's riparian states. This allows for a comparative and cosmopolitan perspective that merges both academic scholarship, as shown by the large number of bibliographic sources, maps, charts, and flow diagrams provided throughout, and fieldwork that delves deeply into the social backgrounds and livelihoods across the region. This approach sharpens the focus on "local nuances" and on advancing alternative priorities, which the authors seek to identify and analyze with a view to presenting a more holistic and multifaceted appreciation of the broad range of water governance issues across the region, through the prism of social justice.

In Part I, an interesting historical narrative, which weaves throughout the book, introduces and considers the influence of national governments and how they might affect how key actors behave, sometimes in ways that are contrary to what one might do voluntarily. For example, in chapter 3, "Local People's Participation in Involuntary Resettlement in Vietnam: A Case Study of the Son La Hydropower Project," Tran Van Ha reveals how, despite an increasingly conscious water ethic society that seeks to limit the state's freedom of action, the resulting resettlement policies have "not led to the desired equitable socio-economic development outcomes as expected" (p 59). He concludes, as summarized by the editors of the book, "that the risks posed by large-scale infrastructure are being, or will still largely be, borne by the poor and other disadvantaged groups" (p 247).

This section of the book also highlights how planners influence agendas that privilege economic efficacy over social equity and how bureaucracies have the capacity to sideline or limit political participation because of their control over relevant information. For example, in Chapter 2, "Water Transfer Planning in Northeast Thailand: Rhetoric and Practice," Philippe Floch and David Blake scrutinize how participatory rhetoric invoked by Thai planners favored conventional knowledge provided by state actors, violating the core principle of communicative planning, and consequentially turning what they cite as "a blind eye to the more complex issues" of barriers to participation, and "the competing vested interests within and between ministries and regional politics" (Middleton 2007 cited in Chapter 2, p 31).

Part II includes interesting contributions that explore how power arises among various ethnic groups through the creation of social doxa: widely held beliefs or opinions. For example, in Chapter 4, "Rights and Rites: Local Strategies to Manage Competition for Watershed Resources in Northern Thailand," Nathan Badenoch and Prasit Leepreecha analyze how the Hmong people, an ethnic minority group that originates from China and who supported themselves by cultivating upland rice and poppy, artificially reconstructed their cultural identities from unethical polluters to guardians of the "watershed" through practices such as the ntoo seeb ceremony: a strategy intended not only to respond to local resource tensions 
but also to assert the legitimacy of their livelihood practices within watershed governance discourses (pp 68-89).

Part III offers critical insights into how a range of actors in this sector shape agendas in critical areas such as food security and climate change. In Chapter 7, "Fisheries, Nutrition and Regional Development Pathways: Reasserting Food Rights," Robert Arthur, Richard Friend, and Mark Dubois evaluate the way in which the World Bank and Asian Development Bank (2006, p 64) report downplayed the impact of hydrodams on fisheries and food security, "placing faith instead on the ability of science to identify some future mitigation," and representing what they view as a "leap of blind faith that puts the most basic developmental rights of people to food at risk" (p 161).

Part IV takes the issue of climate change to the local level and demonstrates the harsh realities of its impacts on stakeholders. In Chapter 10, for example, "Linking Climate Change Risks and Rights of Upland Peoples in the Mekong," Jianchu Xu and Rajesh Daniel critique how Thai officials classified many ethnic groups or "hill tribes" as sociopolitical refugees, depriving them of citizenship and social welfare provisions, and thus increasing their vulnerabilities to the uncertain impacts of climate change. The critical question, therefore, raised by them is "how are local voices heard and whose agenda counts in the decision-making process?" (pp 229-230).

Finally, Part V concludes with a collective essay by the editors on how justice might be "ensured" through improved governance across the Mekong. They postulate that, whereas, "participation may potentially be a tipping point in favour of fairer water governance regimes," this is only possible if the "social conditions" and the "relations of difference and power" are thoroughly interrogated.

Drawing upon the work of Franks and Cleaver (2007), they argue that focusing on "what is actually done," offers better prospects than focusing on "what should be done," because this will help "identify opportunities for adopting and actualizing more redistributive and representative principles of social justice in water governance," and also in "reducing the burden on those that are more palpably socially exclusive and risky to social welfare” (pp 249-251). Issues related to social inequities and injustice, including in the water governance scenario, also are addressed in legal scholarship, which might supplement the authors' findings.

In all, this book is to be commended for its local storytelling, which effectively reveals how a number of water-management practices and emergent priorities have led to socially unjust and inequitable outcomes. For social science students, scholars, water practitioners, and policy-makers interested in this region, the book's framing of development objectives in terms of livelihood security and household dependence on seasonal river flows and wetland inundation certainly offers thoughtful observations into potential alternative priorities and approaches, which are often neglect- ed when viewed from a purely regional economic perspective. For readers who are seeking a more radical and critical paradigm, that is, one that is truly inter- and multidisciplinary (including legal scholarship at the international and national levels across the region), nonanthropocentric, and inclusive of a plurality of perspectives, this book might not quench their thirst but certainly goes far in whetting the appetite for more.

\section{REFERENCES}

Franks T, Cleaver F. 2007. Water governance and poverty: A framework for analysis. Progress in Development Studies 1:291-306.

Glassman J. 2010. Bounding the Mekong: The Asian Development Bank, China, and Thailand. Honolulu, HI: University of Hawai'i Press.

Middleton C. 2007. The ADB / WB / MRC Mekong Water Resources Assistance Strategy: Justifying Large Water Infrastructure with Transboundary Impacts. Critical Transitions in the Mekong Region. Chiang Mai, Thailand: Regional Center for Sustainable Development.

World Bank and Asian Development Bank. 2006. Future Directions for Water Resources. Management in the Mekong River Basin: Mekong Water Resources Assistance Strategy. Manila, The Philippines: World Bank and Asian Development Bank.

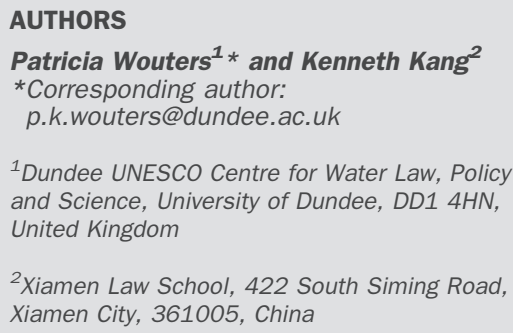

${ }^{1}$ Dundee UNESCO Centre for Water Law, Policy and Science, University of Dundee, DD1 4HN, United Kingdom

${ }^{2}$ Xiamen Law School, 422 South Siming Road, Xiamen City, 361005, China

Open access article: please credit the authors and the full source. 